Jurnal Ilmiah Kanderang Tingang 9(1) (2018) 39-50

ISSN 2087-166X

Januari-Juni 2018
Fakultas Keguruan dan Ilmu Pendidikan

Universitas Palangka Raya

Email:info@chem.upr.ac.id Web:www.chem-upr.education/ojs

\title{
Pembelajaran Sejarah Indonesia Berbasis Peristiwa-Peristiwa Lokal Di Kalimantan Tengah Untuk Meningkatkan Kemampuan Berpikir Kritis
}

\author{
Endang Hartati \\ Guru SMA Negeri 4, Palangka Raya, Indonesia
}

\begin{abstract}
Abstrak : Artikel ini membahas pentingnya pengajaran sejarah lokal di sekolah-sekolah yang dikembangkan. Belajar sejarah atau kejadian lokal masih dirasakan sebagai beban oleh para guru. Penyebabnya adalah kurangnya guru kreatif dalam mengembangkan materi sejarah, mereka berfokus pada materi yang tercantum dalam silabus sejarah pengajaran dan minimal atau tidak ada sumber sejarah lokal yang dapat digunakan oleh guru sebagai bahan ajar di sekolah. Makalah ini berfokus pada urgensi belajar sejarah lokal, yang terintegrasi dengan pengajaran sejarah di Indonesia. Lebih banyak penelitian dilakukan secara khusus terhadap karakter dan peristiwa yang terjadi di wilayah Kalimantan Tengah. Dalam penelitian ini, penulis menunjukkan bahwa di Kalimantan Tengah harus ada banyak karakter dan acara lokal yang harus mendapat perhatian serius dari semua pihak untuk dikembangkan dalam pengajaran sejarah di sekolah. Hal ini sangat penting mengingat pengembangan karakter harus dimulai dari kesadaran akan identitas mereka sebagai bagian dari sejarah Indonesia. Oleh karena itu, perkembangan sejarah lokal merupakan bagian dari pengembangan identitas sebagai bangsa Indonesia.
\end{abstract}

\section{Kata Kunci: Nasionalisme, Patriotisme, Toleransi}

\section{Pendahuluan}

Proses pembelajaran merupakan serangkaian aktivitas yang terdiri dari persiapan, pelaksanaan, dan evaluasi pembelajaran. Ketiga hal tersebut merupakan rangkaian utuh yang tidak dapat dipisahkan. Persiapan pembelajaran pembelajaran merupakan penyiapan perangkat pembelajaran yang meliputi tujuan pembelajaran , alat evaluasi, bahan ajar, metode pembelajaran, media, fasilitas, waktu, tempat, dana, harapan-harapan, dan perangkat informasi yang diperlukan untuk mendukung pelaksanaan proses pembelajaran. Kesiapan siswa, baik fisik maupun mental juga merupakan hal penting. Jadi, esensi persiapan proses pembelajaran adalah kesiapan segala hal yang diperlukan untuk berlangsungnya proses pembelajaran (Ibrahim, 2018).

Pembelajaran sejarah adalah salah satu upaya yang tepat untuk menyelipkan pendidikan nilai multikultural di dalamnya. Sjamsuddin dan Ismaun (1996: 10) mengemukakan bahwa "Sejarah adalah suatu ilmu pengetahuan tentang rangkaian kejadian yang berkausalitas pada masyarakat manusia dengan segala aspeknya serta proses gerak perkembangannya dari awal sejarah hingga saat kini yang berguna bagi pedoman kehidupan masyarakat masa sekarang serta arah cita-cita masa depan". (Hardiana,2017).

Masalah urgen yang seringkali terabaikan dalam pembelajaran sejarah Indonesia, yakni minimnya pembahasan materi sejarah lokal atau peristiwa lokal. Guru sejarah seringkali terpaku pada bahan ajar yang tertuang dalam buku paket mata pelajaran. Guru sejarah jarang memberikan materi pengayaan sejarah Indonesia, khususnya berbasis peristiwa lokal, dengan dalih mengejar target kurikulum. Namun, tidak dipungkiri bahwa tidak sedikit guru sejarah yang 
kesulitan dalam mengembangkan materi peristiwa lokal dalam pembelajaran sejarah Indonesia. Salah satu penyebabnya adalah minimnya referensi tentang peristiwa-peristiwa lokal tersebut (Hardiana,2017). Pembelajaran sejarah yang berlangsung selama ini yang belum mengintegrasikan peristiwa lokal. Salah satu strategi mengajarkan sejarah lokal adalah melalui pembelajaran sejarah di sekolah pentingnya. Dalam kurikulum 2013 dengan pendekatan saintifik memungkinkan strategi terserbut dapat dilaksanakan.

Sejarah Lokal erat kaitannya dengan sikap nasionalisme. Nasionalisme adalah satu paham yang menciptakan dan mempertahankan kedaulatan sebuah negara (nation) dengan mewujudkan satu konsep identitas bersama untuk sekelompok manusia. Substansi nasionalisme Indonesia mempunyai dua unsur: pertama; kesadaran mengenai persatuan dan kesatuan bangsa Indonesia yang terdiri atas banyak suku, etnik, dan agama. Kedua, kesadaran bersama bangsa Indonesia dalam menghapuskan segala bentuk penjajahan dan penindasan dari bumi Indonesia. Hal inisenadadengan yang diungkapkan oleh Soemitro(1994:32)sebagai berikut. Realita geografik, kultural dan etnikal, Nusantara ini dihuni oleh ratusan suku dengan budaya yang beragam serta kepercayaan dan agama yang berbedabeda. Fakta ini mendorong para perintis kemerdekaan dalam era idealisasi perjuangan menganut paham bahwa bangsa adalah kelompok masyarakat yang memiliki latar belakang sejarah, nasib, tujuan dan cita-cita yang sama. Rumusan inilah yang menyatukan seluruh suku bangsa di Indonesia ini menjadi satu bangsa. Dan rumusan ini pulalah yang secara empiris berhasil mengantar bangsaIndonesia ke gerbang kemerdekaan.

Berangkat dari asumsi tersebut selayaknya pula kalau sikap nasionalisme yang harus ditunjukkan oleh warga bangsa adalah nasionalisme yang berlandaskan pada pemahaman sejarah perjuangan masyarakat di masing masing daerah dan persepsi terhadap budaya daerah yang benar sebagai pembentuk identitas Indonesia secara utuh. Pemahaman kembali ketangguhan dan keuletan berbagai daerah berarti merajut lebih rapi lagi kesatuan dan persatuan bangsa. Komunitas bangsa yang terdiri atas kesatuan suku bangsa dan kesatuan etnis tidak tumbuh sendiri, terbentuk melalui proses sejarah yang panjang. Jati diri bangsa merupakan hasil terjadinya proses pematangan integrasinasional (Abdullah, 1996:13).

Akan tetapi mempelajari sejarah seringkali belum dipahami sebagai upaya menumbuhkan sikap nasionalisme, terlebih sejarah daerah yang seringkali dianggap kurang unik dan kurang penting. Sehubungan dengan hal tersebut Bambang Purwanto (2006) mengemukakan, jika prinsip sejarah sebagai sesuatu yang unik diterapkan, maka dapat dikatakan bahwa semua sejarah sebenarnya adalah sejarah lokal. Sementara itu sejarah nasional tidak lain hanya merupakan representasi politism dari sejarah lokal dalam bingkai dimensi keruangan yang baru, ketika perkembangan nasionalisme berhasil menciptakan identitas baru dalam konteks negara bangsa. Sejarah nasional pada dasarnya adalah sekumpulan 
sejarah lokal dalam bingkai keruangan yang lebih luas lagi, dengan demikian memahami sejarah lokal sebagai upaya menumbuhkan.

sikap nasionalisme sama pentingnya dengan memahami sejarah nasional. Di samping sejarah perjuangan rakyat daerah, yang tidak kalah pentingnya adalah keberagaman budaya daerah. Seperti dijelaskan dimuka bahwa nasionalisme Indonesia terbentuk di tengah keberagaman budaya tiap daerah, sehingga tidak bisa dipungkiri bahwa budaya Indonesia pada hakikatnya merupakan perwujudan dari budaya-budaya daerah itu sendiri. Persepsi yang benar terhadap keberagaman budaya akan mampu mengarahkan setiap masyarakat di daerah untuk memiliki identitas dan karakter yang kuat sebagai manusia Indonesia dalam bingkai multikulturalisme. Selain hal tersebut, perjalanan sejarah dari banyak negara besar membuktikan bahwa bangsa yang mampu berkembang menjadi bangsa pesaing ditingkat dunia adalah bangsa yang mempunyai identitas budaya yang kuat dan mampu mempertahankan keluhuran akarbudaya mereka.

\section{Metode}

\section{Jenis dan Sumber Data}

Data merupakan sumber informasi yang didapatkan oleh penulis melaluipenelitian yang dilakukan. Data yang diperoleh nantinya akan diolah sehingga menjadi informasi baru yang dapat dimanfaatkan oleh pembacanya. Dalam penelitian ini, data diperoleh yaitu data sekunder. Data sekunder ini seperti buku-buku mengenai teori-teori perpustakaan, teori sejarah pendidikan, dan bukubuku lain sejenis yang berhubungan dengan kenyamanan membaca pustaka. Data sekunder juga didapatkan dari jurnal-jurnal penelitian yang relevan.

\section{Metode Pengumpulan dan Analisis Data}

Metode yang digunakan untuk mengumpulkan data dalam penelitian ini adalah studi pustaka dengan teknik dokumenter. Studi pustaka dengan teknik dokumenter adalah cara mengumpulkan data melalui peninggalan tertulis seperti arsip-arsip, dan termasuk buku-buku tentang pendapat, teori, dalil atau hukum dan lain-lain yang berhubungan dengan masalah penelitian. Pada penelitian kualitatif teknik ini merupakan alat pengumpul data yang utama. Analisis data pada penelitian ini dilakukan review terhadap beberapa pustaka pendukung baik buku teks maupun jurnal yang dirangkum menjadi suatu fakta berdasarkan data empiris yang ada dari berbagai pustaka.

\section{Hasil Dan Pembahasan}

\section{Urgensi Pembelajaran Sejarah Lokal}

Guna memahami urgensi dari pembelajaran sejarah lokal, perlu difahami terlebih dahulu apa yang dimaksud dengan sejarah lokal. Taufik Abdullah (Mulyana \& Gunawan, 2007:2) mengemukakan bahwa: "Sejarah lokal dapat didefenisikan sejarah dari suatu "tempat", suatu "locality", yang batasannya ditentukan oleh perjanjian yang diajukan penulis sejarah". Selanjutnya Widja 
(Mulyana \& Gunawan, 2007:2) menjelaskan "Batasan yang dibuat oleh penulis bisa luas baik dalam aspek keruangannya maupun aspek tema kajiannya. Kajian sejarah lokal yaitu studi tentang kehidupan masyarakat atau khususnya komunitas dari suatu lingkungan sekitar (neighborhood) tertentu dalam dinamika perkembangannya dalam berbagai aspek kehidupan manusia”.

Corak studi sejarah lokal yang telah dilakukan tentang Indonesia menurut Taufik Abdullah (Supardi, 2006:124) dapat dibedakan menjadi empat golongan, yakni: (1) Studi yang difokuskan pada suatu peristiwa tertentu (studi peristiwa khusus atau apa yang disebut evenemental l'evenement), (2) Studi yang lebih menekankan pada struktur, (3) Studi yang mengambil perkembangan aspek tertentu dalam kurun waktu tertentu (tematis), dan (4) Studi sejarah umum yang menguraikan perkembangan daerah tertentu (provinsi, kota, kabupaten) dari masa ke masa.

Dalam konteks mengembangkan sejarah lokal, diperlukan pendidikan yang mampu menanamkan nilai-nilai multikultural dalam kehidupan peserta didik agar tercipta generasi muda yang mampu menciptakan keharmonisan dalam bermasyarakat. Hasan (2012: 102) mengemukakan pendapat bahwa "Pendidikan adalah suatu usaha sadar manusia mempersiapkan generasi mudanya. Dalam mempersiapkan generasi muda tersebut pendidikan harus mulai dari apa yang sudah dimilikinya dan apa yang sudah diketahuinya. Apa yang sudah dimilikinya dan sudah diketahuinya itu adalah apa yang terdapat pada lingkungan terdekat peserta didik terutama pada lingkungan budayanya. Prinsip ini berkenaan dengan cara bagaimana peserta didik belajar". Pembelajaran sejarah adalah salah satu upaya yang tepat untuk menyelipkan pendidikan nilai multikultural di dalamnya. Sjamsuddin dan Ismaun (1996:10) mengemukakan bahwa "Sejarah adalah suatu ilmu pengetahuan tentang rangkaian kejadian yang berkausalitas pada masyarakat manusia dengan segala aspeknya serta proses gerak perkembangannya dari awal sejarah hingga saat kini yang berguna bagi pedoman kehidupan masyarakat masa sekarang serta arah cita-cita masa depan”.

Dalam kaitan dengan hal itu, Winarti (XX:6) menjelaskan bahwa ada beberapa hal pentingnya mempelajari sejarah lokal antara lain: (1) Untuk menilai kembali generalisasi-generalisasi yang sering terdapat dalam sejarah nasional (periodisasi,dualisme ekonomi,dll.), (2) Meningkatkan wawasan/ pengetahuan kesejahteraan dari masing-masing kelompok yang akhirnya akan memperluas pandangan tentang "dunia" Indonesia, (3) Membantu sejarawan profesional membuat analisis-analisis kritis. Dan, (4) Menjadi sumber/ bahan/ data sejarah dalam penelitian.

Hal tersebut dipertegas oleh Supardan (2004:262) yang menyatakan bahwa "Pembelajaran sejarah lokal perlu dikenalkan pada siswa untuk mengenali identitas kelokalannya maupun menghargai identitas etnis/daerah lain yang ada di Indonesia dengan mempertimbangkan azas belajar dan tahap perkembangan siswa. Pemerintah pusat dan daerah, guru-guru sejarah dilapangan harus berusaha 
sekuat-kuatnya utnuk mendorong terlaksananya pembelajaran sejarah lokal di sekolah-sekolah".

Dengan pembelajaran sejarah yang berbasis sejarah lokal, maka guru akan dengan mudah menamkan nilai-nilai multikulturalisme dalam diri peserta didik. Mahendrawati dan Syafei (Naim \& Achmad Sauqi, 2012:126) mengemukan bahwa "Multikulturalisme sebenarnya merupakan konsep dimana sebuah komunitas dalam konteks kebangsaan dapat mengakui keberagaman, perbedaan, dan kemajemukan budaya, baik ras, suku, etnis dan agama. Sebuah konsep yang beragam (multikultur). Bangsa yang multikultur adalah bangsa yang kelompokkelompok etnik atau budaya (etnic and cultural groups) yang ada dapat hidup berdampingan secara damai dalam prinsip co-existence yang ditandai oleh kesediaan untuk menghormati budaya lain. Pluralitas ini juga ditangkap oleh agama, selanjutnya agama mengatur untuk menjaga keseimbangan masyarakat yang plural tersebut".

Hasan (2012:6) mengemukakan tujuan pendidikan sejarah sebagai bagian dari pendidikan IPS adalah: (1) Memiliki pengetahuan dan pemahaman tentang berbagai peristiwa sejarah penting dan esensial untuk membangun memori kolektif sebagai bangsa, (2) Mengembangkan semangat kebangsaan, (3) Mengembangkan daya berfikir kritis dan kreatif, (4) Mengembangkan rasa ingin tahu, (5) Preservasi kecemerlangan masa lalu, (6) Mengembangkan kejujuran, kerja keras dan tanggungjawab, (7) Mengembangkan nilai dan sikap kepahlawanan, kepemimpinan dan inspirasi, (8) Mengembangkan persahabatan dan kepedulian social, (9) Mengembangkan kemampuan komunikasi, (10) Mengembangkan kemampuan mencari, mengolah, mengemas dan mengkomunikan informasi.

Hal ini dipertegas oleh Wiriatmadja (2002:156-157) yang mengemukakan bahwa Pengajaran sejarah adalah untuk membangkitkan kesadaran empatik (emphatic awareness) di kalangan peserta didik, yaitu sikap empati dan toleransi terhadap orang lain yang disertai dengan kemampuan mental untuk imajinasi dan kretivitas, jika sejarah dipahami dengan benar oleh peserta didik. Pengajaran sejarah nasional di sekolah, bagaimanapun akan memperkenalkan peserta didik kepada pengalaman kolektif dan masa lalu bangsanya. Pengajaran ini juga membangkitkan kesadaran dalam kaitannya dengan kehidupan bersama dalam komunitas yang lebih besar, sehingga tumbuh kesadaran kolektif dalam memiliki kebersamaan dalam sejarah. Proses pengenalan diri inilah yang merupakan titik awal dari timbulnya rasa harga diri, kebersamaan, dan keterikatan (sense of solidarity), rasa keterpautan dan memiliki (sense of belonging) kemudian rasa bangga (sense of pride) terhadap bangsa dan tanah air. Dari gambaran di atas, dapat diambil sebuah konklusi bahwa urgensi pembelajaran sejarah local dalam pembelajaran sejarah nasional terlihat dari adanya korelasi yang sangat erat terkait keberadaan peristiwa lokal dalam sejarah nasional Indonesia. 


\section{Peristiwa-Peristiwa Lokal di Kalimantan Tengah}

Kalimantan Tengah seperti daerah lainnya, merupakan salah satu bagian dari wilayah Negara Kesatuan Republik Indonesia. Sebagai daerah yang tidak begitu jauh dengan pusat kekuasaan provinsi dan pusat. Kalimantan Tengah memiliki peristiwa-peristiwa lokal yang secara langsung maupun tidak langsung mempengaruhi jalannya roda sejarah bangsa Indonesia. Peristiwa-peristiwa lokal tersebut ada yang bernuansa politik, sosial, ekonomi, maupun budaya. Bahkan ada beberapa peristiwa di Kalimantan Tengah yang telah menjadi wacana sejarah nasional. Dari sekian banyak peristiwa-peristiwa lokal di Kalimantan Tengah, diantaranya ialah:

\begin{tabular}{|c|c|c|}
\hline Periodisasi Peristiwa & Materi Pokok Pelajaran & Peristiwa Lokal Kalteng \\
\hline Masa Pra Aksara & $\begin{array}{l}\text { Ciri-ciri Kehidupan Manusia } \\
\text { Purba }\end{array}$ & $\begin{array}{l}\text { Peninggalan Purbakala di pesisir } \\
\text { sungai Kalimantan dan kompleks } \\
\text { Gua Niah }\end{array}$ \\
\hline \multirow[t]{2}{*}{ Masa Hindu-Budha } & $\begin{array}{l}\text { Kerajaan Bercorak Hindu } \\
\text { Budha }\end{array}$ & $\begin{array}{l}\text { Negara Bagian Tanjung (Negara } \\
\text { yang tunduk kepada Majapahit). } \\
\text { Sebagian besar kerajaan di } \\
\text { Kalimantan dipengaruhi budaya } \\
\text { Islam, meskipun } \\
\text { Kaharingan juga masih dianut } \\
\text { sebagian masyarakatnya. }\end{array}$ \\
\hline & Tokoh-Tokoh Masa Hindu & Nyai Undang, Tambun Bungai \\
\hline \multirow{3}{*}{ Masa Islam } & Kerajaan Bercorak Islam & Kerajaan Kuta Ringin \\
\hline & Tokoh-Tokoh Masa Islam & Sultan Mustain Billah \\
\hline & Saluran Penyebaran Islam & $\begin{array}{l}\text { Kesultanan Banjar } \\
\text { Menurut perjanjian VOC-Belanda }\end{array}$ \\
\hline \multirow[t]{2}{*}{$\begin{array}{l}\text { Masa Kolonialisme } \\
\text { Barat }\end{array}$} & Masa VOC & $\begin{array}{l}\text { dengan kesultanan Banjar Negeri } \\
\text { Kotawaringin adalah negara } \\
\text { dependensi dalam negara Banjar }\end{array}$ \\
\hline & $\begin{array}{l}\text { Karakteristik Organisasi } \\
\text { Pergerakan Nasional }\end{array}$ & $\begin{array}{l}\text { Serikat Dayak dan Koperasi Dayak } \\
\text { (Pakat Dayak) }\end{array}$ \\
\hline $\begin{array}{l}\text { Masa Pergerakan } \\
\text { Nasional }\end{array}$ & Peristiwa Penting & $\begin{array}{l}\text { Pertempuran suku Dayak Punan } \\
\text { (Oot Marikit) }\end{array}$ \\
\hline Indonesia & $\begin{array}{l}\text { Tokoh-Tokoh Masa Pergerakan } \\
\text { Nasional }\end{array}$ & $\begin{array}{l}\text { Hausman Babu, Anton Samat, } \\
\text { Loei Kamis }\end{array}$ \\
\hline & & $\begin{array}{l}\text { Maklumat tentara Jepang tentang } \\
\text { penyerahan Provinsi Borneo ke }\end{array}$ \\
\hline $\begin{array}{l}\text { Masa Pendudukan } \\
\text { Jepang }\end{array}$ & Peristiwa Penting & $\begin{array}{l}\text { Pimpinan Pemerintah Civil, } \\
\text { Penerbitan surat kabar Kalimantan } \\
\text { Raya }\end{array}$ \\
\hline & Tokoh Masyarakat & $\begin{array}{l}\text { Kiai Pangeran Musa Ardi Kesuma } \\
\text { sebagai Ridzi (Kalsel dan Kalteng) }\end{array}$ \\
\hline & Organisasi & Komite Kesadaran Suku Dayak \\
\hline Masa Perang & Perkembangan Ekonomi & $\begin{array}{l}\text { Koperasi Dayak dalam upaya } \\
\text { mengejar ketertinggalan derajat } \\
\text { suku, baik dalam bidang politik, } \\
\text { sosial, ekonomi. }\end{array}$ \\
\hline $\begin{array}{l}\text { Kemerdekaan } \\
\text { Indonesia }\end{array}$ & $\begin{array}{l}\text { Tokoh-Tokoh Masa Perang } \\
\text { Kemerdekaan Indonesia }\end{array}$ & $\begin{array}{l}\text { Mahir mahar, C. Luran, H. } \\
\text { Nyangkal, Oto Ibrahim, Philips } \\
\text { Sinar, E.S. Handuran, Amir Hasan, } \\
\text { Christian Nyunting, Tjilik Riwut }\end{array}$ \\
\hline $\begin{array}{l}\text { Sejarah Seni dan } \\
\text { Budaya }\end{array}$ & Hasil-Hasil Seni dan Budaya & $\begin{array}{l}\text { Asal Usul kerajinan Batik Benang } \\
\text { Bintik Kalteng (Filosofi Batang }\end{array}$ \\
\hline
\end{tabular}


Jurnal Ilmiah Kanderang Tingang 9(I) (2018) 39-50 ISSN 2087-166X

Januari-Juni 2010
Fakultas Keguruan dan Ilmu Pendidikan

Universitas Palangka Raya

Email:info@chem.upr.ac.id Web:www.chem-upr.education/ojs

Garing), Kerajinan Gita Nyatu, Anyaman Rotan, Falsafah Huma Betang, Karungut, Seni Ukir dan Pahat, Upacara adat : Tiwah, Manyanggar, Mamapas Lewu, Mampakanan Sahur Parapah.

\section{Implementasi Pembelajaran Sejarah Lokal di Sekolah}

Dalam pembelajaran sejarah lokal, terdapat beberapa hal yang harus diperhatikan yaitu pertama penyajian materi, kedua teknik pembelajaran dan ketiga penilaian yang digunakan. Sebagaimana telah dikemukan bahwa pendekatan pembelajaran sejarah lokal jangan hanya sekedar menampilkan sejarah sebagai peristiwa saja. Pembelajaran sejarah lokal pun harus mengikuti kecenderungan perkembangan penulisan sejarah pada umumnya. Perkembangan penulisan sejarah dirincikan dengan menekankan analisis daripada bercerita; menekankan tema-tema atau topik-topik daripada kronologi; mengandalkan statistik, wawancara lisan, model-model sosiologi dan teori psiko-analisis. Fokus baru dalam penulisan sejarah yaitu kelompok-kelompok sosial seperti keluarga, masalah-masalah sosial, pabrik dan perusahaan, kelahiran dan kematian, masa kanak-kanak dan masa tua, kriminalitas dan penyakit kejiwaan. Penulisan sejarah baru tidak lagi menekankan kepada penulisan kelompok elite (Mulyana \& Restu Gunawan, 2007:7).

Pembelajaran sejarah lokal, dapat dimplementasikan di sekolah melalui pembelajaran sejarah nasional. Dalam arti lain, peristiwa-peristiwa lokal dapat disisipkan dalam pembelajaran sejarah nasional, dengan cara mencari kesuaian tema/pokok bahasan dalam Silabus Sejarah Nasional dan dijabarkan dalam bentuk modifikasi Rencana Pelaksanaan Pembelajaran (RPP) yang mengembangkan kreatifitas berfikir siswa. Hal ini dapat dilakukan dengan cara mengembangkan kemampuan berfikir siswa secara kritis. Dalam hal ini, Hasan (2008:5) mengemukakan, bahwa: "Kemampuan berfikir kritis dalam sejarah adalah kemampuan mencari dan menentukan sumber informasi yang valid, kemampuan mengumpulkan informasi dari berbagai sumber sejarah, kemampuan mengelompokkan informasi tersebut dalam berbagai klasifikasi, kemampuan menentukan hubungan antar informasi dalam klasifikasi dan antarklasifikasi, kemampuan memberi makna terhadap hubungan informasi, kemampuan membangun cerita sejarah. Kemampuan keterkaitan antar informasi haruslah berdasarkan kemampuan dalam menerapkan pemahaman mengenai hubungan sebab akibat dan kemampuan interpolasi" Secara spesifik dalam konteks pembelajaran sejarah lokal kemampuan berfikir kritis tersebut disesuaikan jenjang pendidikan peserta didik, seperti yang dijelask oleh Hasan dalam Mulyana (2007:189-190), berikut ini: "Pada jenjang pendidikan menengah (SMA), tujuan pendidikan sejarah lebih dikembangkan untuk mempersiapkan peserta didik untuk meniti pendidikan pada jenjang pendidikan tinggi. Karena itu, tulisan ini menekankan untuk mengembangkan kemampuan pemahaman maupun skills yang 
diperlukan dalam sejarah. Kemampuan yang dimaksud seperti historical thinking, historical analysis and interpretation, dan historical research capability dapat dikembangkan sebagi focus utama. Dalam kaitan dengan hal ini, posisi materi sejarah local yaitu peristiwa sejarah lokal tidak lagi sebagai sumber semata tetapi juga menjadi objek studi sejarah peserta didik. Dalam kesempatan inilah mereka belajar mengembangkan wawasan, pemahaman, dan keterampilan sejarah. Mereka dapat berhubungan langsung dengan sumber asli dan mengkaji sumber asli dalam suatu proses penelitian sejarah. Mereka dapat melatih diri dalam penafsiran sejarah dan kalau pun terjadi berbagai perbedaan di antara mereka maka itu akan memiliki nilai pendidikan yang sangat tinggi.

Pendekatan pembelajaran sejarah yang tepat, Supriatna (2005:113-131) mengemukan pendekatan konstruktivisme, seperti dijelaskan berikut ini: "pendekatan konstruktivisme dalam pembelajaran sejarah yang bermuara pada pengembangan kemampuan guru dalam membangkitkan kemampuan berfikir kritis siswa. Pendekatan konstruktivisme dapat digunakan oleh guru sejarah dalam mengembangkan materi ajar di kelas. Selama ini, pengajaran sejarah di sekolah masih menggunakan pendekatan tradisional seperti ceramah, diskusi, dan lainlain, serta lebih menekankan pada aspek-aspek kognitif dan mengabaikan keterampilanketerampilan social dalam sejarah. Konsekuensi dari metode tersebut adalah siswa merasa bosan terhadap materi pelajaran sejarah dan dalam jangka panjang, tentu saja, akan menjadi penurunan kualitas pembelajaran sejarah.

Pendekatan konstruktivisme mengharuskan guruguru untuk melakukan hal-hal berikut ini: (1) mendorong dan menerima otonomi dan inisiatof siswa dalam mengembangkan materi pembelajaran, (2) menggunakan data mentah dan sumber utama (primary resources), termasuk sumber-sumber pelaku utama sejarah, untuk dikembangkan dan didiskusikan bersama-sama dengan siswa di kelas, (3) memberikan tugas kepada siswa untuk mengembangkan klasifikasi, analisis, melakukan, prediksi terhadap peristiwa sejarah, dan menciptakan konsepkonsep baru, (4) berdifat fleksibel terhadap response dan interpretasi siswa dalam masalah-masalah sejarah, bersedia mengubah strategi pembelajaran yang tergantung pada minat siswa, serta mengubah isi pelajaran sesuai dengan situasi dan kondisi siswa. (5) memfasilitasi siswa untuk memahami konsep sambil mengembangkannya melalui dialog dengan siswa, (6) mengembangkan dialog antara guru dengan siswa dan siswa dengan rekan-rekannya, (7) menghindari alat tes untuk mengukur keberhasilan siswa, (8) mendorong siswa untuk membuat analisis dan elaborasi terhadap masalah-masalah controversial yang dihadapinya, (9) mengembangkan aspek kontrasiksi dan kontroversi untuk ditarik dalam KBM di kelas, (10) member peluang kepada siswa untuk berfikir mengenai masalah yang dihadapi siswa, (11) member peluang kepada siswa untuk membangun jaringan konsep serta membentuk metaphora.

Dalam kurikulum 2013, pendekatan saintifik (mengamati, menanya, mengumpulkan informas, mengasosiasi, dan mengomunikasikan) akan menjadi 
ruh pembelajaran dengan berbagai model pembelajaran. Tiga model yang dikembangkan dalam Kurikulum 2013, seperti PBL (Problem Based Learning), DL (Discovery Learning), dan PjBL (Project Based Learning), akan dapat mengembangkan pembelajaran sejarah local secara optimal. Kondisi tersebut sangat memungkinkan karena melalui kurikulum 2013 pendidikan sejarah akan diakomodir sehingga target yang akan dicapai mengenai sasaran sesuai dengan penjelasan yang telah dipaparkan. Peserta didik akan mampu menganalisa dan memetik pelajaran dari peristiwa sejarah yang telah dipelajarinya di sekolah.

Kurikulum 2013 pendidikan sejarah lebih mempertegas tujuan dari pembelajaran sejarah di sekolah yang mendorong peserta didik agar berfikir kreatif dan kritis. Hasan (2012: iv) mengemukakan bahwa "Dalam wilayah pendidikan, sejarah harus menjadi sesuatu yang memberikan pelajaran bagi kehidupan manusia. Peristiwa-peristiwa sejarah di in dengan pendekatan normatif, dengan melihat baik dan buruk." Oleh karena itu, kurikulum 2013 akan membentuk peserta didik yang memiliki kualitas yang baik, sehingga mampu mengambil nilai baik dan buruknya dari peristiwa sejarah di masa lampau kemudian diolah dalam otak mereka untuk direkonstruksi kembali menjadi sebuah nilai yang positif, mengingat era global yang sedang mereka hadapi. Pendidikan sejarah harus dapat mempersiapkan peserta didik dengan kualitas yang baik. Adapun kualitas yang harus dimiliki peserta didik menurut Marli (XX:4) yakni: “(1) Kualitas yang mampu melakukan kritik terhadap setiap informasi yang harus diterimanya. (2) Mampu mengenal berbagai bias yang terkandung di dalam informasi tersebut. (3) Mampu menarik berbagai simpulan dari informasi tersaring dan teruji kebenarannya. (4) materi pendidikan sejarah harus memiliki kualitas dan karakteristik yang mampu mengembangkankualitas yang dimaksudkan".

Merujuk dari tujuan pendidikan sejarah dan kualitas yang harus dimiliki oleh peserta didik, kurikulum 2013 pendidikan sejarah sudah tepat dengan konteks masa kini. Karena peserta didik akan mampu bersaing di era global tanpa melupakan jati diri bangsa karena mereka telah dibekali kesadaran sejarah dalam pembelajaran di sekolahnya. Sebagai upaya mengenalkan diri peserta didik dengan lingkungannya, pengembagan peristiwa-peristiwa lokal dalam pembelajaransejarah sangatlah urgen dan bagian yang tak terpisahkan dari peristiwa sejarah nasional. Dalam kaitan dengan hal ini, Hasan dalam Mulyana (2007:178-179) mengungkan bahwa: "Dalam posisi arah dan tujuan pendidikan sejarah haruslah mempersiapkan peserta didik untuk hidup di masyarakat. Dalam posisi ini keberadaan sejarah lokal akan memegang posisi utama karena ia berkenaan dengan lingkungan terdekat dengan budaya peserta didik. Sebuah catatan penting dalam konteks tersebut ialah materi sejarah lokal harus pula disajikan tidak dalam perspektif ilmu sejarah tetapi dalam perspektif pendidikan. Oleh karena itu, keterkaitan dan penafsiran materi sejarah lokal jangan sampai menimbulkan konflik dengan kepentingan sejarah nasional dan upaya membangun rasa persatuan, perasaan kebangsaan, dan kerjasama antardaerah 
dalam membangun kehidupan kebangsaan yang sehat, cinta damai, toleransi, penuh dinamika, kemampuan berkompetisi dan berkomunikasi”.

Belajar sejarah berarti peserta didik mampu berpikir kritis dan mampu mengkaji setiap perubahan di lingkungannya, serta memilikikesadaran akan perubahan dan nilai-nilai yang terkandung dalam setiapperistiwa sejarah. Pembelajaran sejarah yang baik adalah pembelajaran yang mampu menumbuhkan kemampuan siswa melakukan konstruksi kondisi masa sekarang dengan mengkaitkan atau melihat masa masa lalu yang menjadi basis topik pembelajaran sejarah. Kemampuan melakukan konstruksiini harus dikemukakan secara kuat agar pembelajaran tidak terjerumus dalam pembelajaran yang bersifat konservatif. Kontekstualitassejarah harus kuat mengemuka dan berbasis pada pengalaman pribadi para siswa. Apalagi sejarah tidak akan terlepas dari konsep waktu, kontinuitas dan perubahan. (Surbakti, 2010: 4)

Pada gilirannya, hal menentukan bahwa pembelajaran sejarah lokal atau kejadian lokal di atas, sangat bergantung pada kemampuan kompetensi guru sejarah itu sendiri. Kreatifitas guru sejarah, dalam hal ini, jelas sangat dituntut untuk mengembangkan peristiwa-peristiwa lokal dalam pembelajaran sejaran di sekolah. Akhirnya, pengakuan jati diri daerah sebagai bagian integarasi bangsa Indonesia, sedikit banyak akan tercapai dan dapat memperkuat keutuhan NKRI.

\section{Kesimpulan}

Peristiwa-peristiwa lokal di atas, merupakan sebagian kecil dari peristiwa lokal yang pernah terjadi di Kalimantan Tengah. Dalam konteks kontemporer, banyak sekali kejadiankejadian lokal di Kalimantan Tengah yang masih perlu digali dan dikembangkan. Diperlukan penelitian dan pengkajian lebih mendalam tentang sejarah lokal, karena masih sedikit sekali sumber sejarah lokal untuk dijadikan bahan ajar dalam pembelajaran sejarah di sekolah. Bahkan, objek kajian penelitian dapat dikembangkan tidak hanya pada sejarah politiknya, akan tetapi setiap perubahan social, budaya, ekonomi yang terjadi di sekitar lingkungan tempat tinggal siswa dapat dijadikan sebagai kajian sejarah.

Selain itu, dalam pembelajaran sejarah berbasis sejarah lokal akan tercapai kearifan lokal dalam diri peserta didik melalui tokoh atau peristiwa yang bersifat lokal sehingga peserta didik peka terhadap lingkungan sekitar, menghargai keragaman budaya serta mengenal jatidirinya. Peristiwa-peristiwa lokal di Kalimantan Tengah, juga di daerah akan mampu menegaskankan identitas/jati diri sebagai bagian dari bangsa Indonesia yang luas dan utuh.

\section{Saran}

Kedepan perlu di buat program serupa yang berkesinambungan dan bertahap, agar nantinya dalam pembelajaran dapat meningkatkan kemampuan berpikir kritis menjadi lebih baik. 


\section{Daftar Pustaka}

Ibrahim, Asriadi. 2018. Pengaruh Metode Pembelajaran dan Kemandirian Belajar terhadap Hasil Belajar Sejarah SMA Negeri 1 Parung, Jurnal Pendidikan Sejarah, Vol. 7, No.1.

Hardina, Yayan. 2017. Pembelajaran Sejarah Indonesia Berbasis PeristiwaPeristiwa Lokal di Tasikmalaya untuk Meningkatkan Kemampuan Berpikir Kritis. HISTORIA :Jurnal Pendidik dan Peneliti Sejarah, Vol. XV, No.1.

Hasan, S. Hamid. 2012. Pendidikan Sejarah Indonesia.Bandung: Rizqi Press.

Hasan, S. Hamid, Pengembangan Kompetensi Berfikir Kritis dalam Pembelajaran Sejarah, Makalah: Seminar IKAHIMSI di UPI, 8 April 2008.

Hasan, S. Hamid, Kurikulum Sejarah dan Pendidikan Sejarah Lokal, dalam Agus Mulyana \& Restu Gunawan. (2007). Sejarah Lokal Penulisan dan Pembelajaran di Sekolah, Bandung: Salamina Press.

Mulyana, Agus \& Restu Gunawan. 2007. Sejarah Lokal Penulisan dan Pembelajaran di Sekolah. Bandung:Salamina Press.

Naim, Ngainun \& Achmad Sauqi. 2012. Pendidikan Multikultural Konsep dan Aplikasi. Yogyakarta: Ar-Ruzz Media.

Sjamsuddin, Helius \& Ismaun. 1996. Pengantar Ilmu Sejarah. Jakarta: Departemen Pendidikan dan Kebudayaan Direktorat Jenderal Pendidikan Tinggi.

Supardan, Dadang 2004. Kesadaran Sejarah BerbasisPendekatan Multikultural dan Perspektif Sejarah Lokal, Nasional, Global dalam Integrasi Bangsa. Disertasi SPS UPI Bandung: Tidak diterbitkan.

Supardi \& Saliman. (XX). Penanaman Nilai dalamPembelajaran IPS di SMP. Pdf Sumber tersedia http://staff.uny.ac.idsystemfilespenelitianSaliman,\%20Drs.\%20M.Pd.Pendid ikan\%20nilai\%20dalam\%20 pembelajaran\%20IPS.pdf (Diakses 23 September 2013).

Supriatna, Nana. Konstruksi Pembelajaran Sejarah Lokal untuk Memahami IsuIsu Sosial, HISTORIA Jurnal Pendidikan Sejarah: No.11. Vol VI (Juni 2005).

Surbakti, Y.R. 2010. Paradigma Pembelajaran Sejarah Berbasis Konstruktivisme. Yogyakarta: Jurnal SPPS Vol. 24 No.1 Sumber tersedia: http://www. usd.ac.idlembagalppmf113Jurnal\%20Historia\%20 Vitae vol 24no1april2010PARADIGMA\%20PEMBELAJARAN\%20SEJARAH\%20 YR\%20Subakti.pdf (Diakses 21 September 2013).

Winarti, Murdiyah. XX. Sejarah Lokal: (Pengertian, Konten dan Pengajaran). Sumber tersedia di: http:// file.upi.eduDirektoriFPIPSJUR._PEND._SEJARAH196005291987032MURDIYAH_WINARTIPeng_sej__Lokal.pdf (Diakses 26 September 2013).

Wiriatmadja, Rochiati. 2002. Pendidikan Sejarah Indonesia, Perspektif Lokal Nasional dan Global. Bandung: Historia Utama Press.

Wineberg, Sam. 2006) Berfikir historis, memetakan masa depan mengajarkan masa lalu. Jakarta: Yayasan Obor Indonesia. 
Winecoff, Herbert L. 1987. Values education: concepts and models. (Indonesia \& State University of New York Technical Assistance Program, A World Bank Sponsored Program). Bandung: Fakultas Pasca Sarjana IKIP Bandung.

Wiria atmadja, R. 2002. Pendidikan sejarah di Indonesia, perspektif lokal, nasional dan global. Bandung: Historia Utama Press. 